\title{
The role of structural strategic cost management techniques in supporting firms' triple bottom line performance in supply chain context ${ }^{1}$
}

\author{
دور أدوات الإدارة الإستراتيجية الهيكلية للتكلفة في دعم الأداء \\ الثلاثي للثركات في نطاق سلسلة التوريد
}

Prepared by: Reham Mohamed Safwat Mohamed

Under supervision of: Prof. Mohamed Mustafa El-Gebally

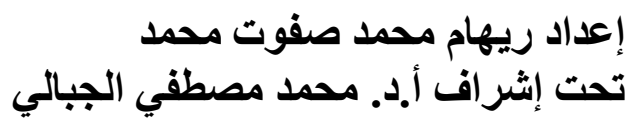

${ }^{1}$ The research is submitted as part of PhD thesis in Accounting titled; "A proposed framework for supporting firm's triple bottom line performance in Supply Chain context through the structural and executional techniques of strategic cost management: an applied study" 
تتاولت القليل من الأدبيات السابقة التطور في أدوات الإدارة الإستراتيجية للتكلفة نتيجة لظهور مفهوم الأداء الثلاثي للثركات (TBL) وخاصة في نطاق سلسلة التوريد، لذلك يهدف هذا البحث إلى دراسة دور أدوات الإدارة الإستراتيجية الهيكلية للتكلفة في دعم الأداء الثلاثي للثركات في نطاق سلسلة التوريد، وتتاول البحث دور التكلفة المستهدفة (TC)، الهندسة المنزامنة ثلاثية الأبعاد (TCET)، نظام إدارة سلسلة التوريد المستدامة (SSCM)

الكلمات المفتاحية: الأداء الثتاثي، سلسلة التوريد، الإدارة الاستراتيجية الهيكلية للتكلفة، التكلفة المستهدفة، الهندسة المتزامنة ثناثية الأبعاد، نظام إدارة سلسلة التوربد المستدامة، ونظام الإنتاج الإنسيابي.

\section{$\underline{\text { Abstract }}$}

Little of previous literature have studied the development in strategic cost management techniques as result of the emergence of the concept of Triple Bottom Line (TBL) performance especially in SC context, this research aims to examine the role of structural strategic cost management techniques in supporting firms' TBL performance in SC context, the research studied the role of Target Costing (TC), Three dimensional concurrent engineering (3DCE), Sustainable supply chain management (SSCM), and Lean manufacturing (LM) in supporting firms' TBL performance.

Key words: TBL performance, SC context, structural strategic cost management, TC, 3DCE, SSCM and LM. 
The role of structural strategic cost management techniques in supporting ريهام صفوت firms' triple bottom line performance in supply chain context

\section{$\underline{\text { Research introduction }}$}

In the field of operations management, priorities traditionally have been related to cost, delivery, lead time, quality and reliability then sustainability was considered as an additional competitive priority. And current studies considered that environmental and social sustainability priority and objectives as an opportunity or a source of creating a competitive advantage (Longoni \& Cagliano 2015, p.217).

Strategic cost management scope covers all costs internal and external to the firm (Shank\& Govindarajan, 1993). Strategic cost management role extends beyond firm's boundaries by analyzing the whole value chains of products and services to increase their cost and value competitiveness (Ellram \& Stanley 2008, p.181).

So firms must focus on environmental sustainability (material, energy and water consumption and pollution reduction) and social sustainability (worker and social well-being) along with the traditional priorities (cost, delivery, quality and flexibility) which are necessary to reach financial objectives and sustainability in current business conditions which lead to the emergence of the concept of firms' TBL performance.

\section{$\underline{\text { Research problem }}$}

Cost management systems are increasingly required to operate across the organizational boundaries and management accounting 
The role of structural strategic cost management techniques in supporting ريهام صفوت firms' triple bottom line performance in supply chain context

control systems are no longer restricted to companies' boundaries but extended across the SCs. Also rapid technological developments and specialization have led to increase the level of environmental uncertainty which led to the use of predictive control models across firms' boundaries (Otley 2016, p. 45).

Recently consumers are preferring environmental friendly products and products that care for society, and they support firms that adopt sustainable manufacturing processes (Mani, Gunasekaran \& Delgado 2018, p.149) which necessitates the integration of social and environment objectives along the financial objectives between the different SC partners and in the different stages of the SC from supplier selecting, logistics, manufacturing, distribution, and after sales services.

While little of previous strategic cost management literature have studied the development in structural strategic cost management techniques as a subsystem of the strategic cost management system, especially in SC context, to support firms' TBL performance which creates a research gap needed to be studied.

\section{$\underline{\text { Research objectives }}$}

The research aims to study:

1. The emergence of the concept of firms' TBL performance

2. TBL performance in SC context

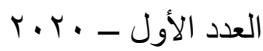

NT مجلة المحاسبة و المر اجعة لإتحاد الجامعات العربية 
The role of structural strategic cost management techniques in supporting ريهام صفوت

firms' triple bottom line performance in supply chain context

3. Structural strategic cost management as a subsystem of strategic cost management system

4. The development in structural strategic cost management techniques as result of firms' TBL performance

5. The role of structural strategic cost management techniques in supporting firms' TBL performance.

\section{$\underline{\text { Research plan }}$}

According to research problem and objectives the research will be continued as follows;

1. TBL performance in SC context

2. Structural strategic cost management

3. The role of structural strategic cost management

techniques in supporting firms' TBL performance

4. Research conclusions and future studies

5. References.

\section{1- $\quad$ TBL performance in SC context}

The concept of TBL was first introduced by Elkington in 1990's (Schulz \& Flanigan, 2016, p.451, Henao, Sarache, and Gómez, 2019, p.100), The TBL represents the three dimensions or components of sustainability: social, environmental and financial sustainability, the TBL concept has been subsequently adopted by 
The role of structural strategic cost management techniques in supporting ريهام صفوت firms' triple bottom line performance in supply chain context

firms to satisfy their social and environmental responsibilities and to achieve their sustainability objectives.

The concept of the TBL proposes that the integration between firms' financial, environmental and social objectives would create activities that would achieve long term financial benefits and support their competitive advantages along with satisfying their environmental and social responsibilities (Carter \& Rogers 2008, p.365).

SC refers to the flow of goods, services and information from the original sources of raw materials to the delivery of finished product and services to customers, whether activities shall be conducted in the same organization or different organizations.

Supply Chain Management (SCM) could help firms in achieving social and environmental performance objectives by;

1. Providing more opportunities for social and environmental friendly innovations

2. Ensuring the provision of green, environmental friendly and safe materials and inputs

3. Supporting joint planning and engagement in mutual environment protection and social programs

4. Facilitating the creation of green and socially responsible brand.

And accordingly one of the main challenges of SC design is to select SC members those are integral to achieving long-term broad

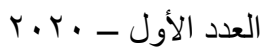
10 مجلة المحاسبة و المراجعة لإتحاد الجامعات العربية 
The role of structural strategic cost management techniques in supporting ريهام صفوت firms' triple bottom line performance in supply chain context

TBL objectives to help in reaching firm's long term SC sustainability (Varsei, et al., 2014, p.243).

That led to the emergence of the concept of Sustainable supply chain management (SSCM) which would be negotiated in detail in next sections of this research.

\section{2- Structural strategic cost management}

Shank \& Govindarajan (1993) defined strategic cost management as "the strategic use of cost information explicitly directed to one or more of the four stages of strategic management" those are (Shank \& Govindarajan, 1993 p.6-8);

1. Strategies formulation

2. Communicating strategies through firm

3. Developing tactics to implement the strategies

4. Developing and implementing controls to follow up the success in achieving strategy related objectives.

Drawing on the work of Shank and Govindarajan $(1992,1994)$ and Tomkins and Carr (1996), Anderson (2006) describes two forms of Strategic cost management: (i) structural cost management, and (ii) executional cost management, Both of them are basic for profitable firms (Anderson \& Dekker, 2009b, p.290).

The purpose of strategic cost management is to align a firm's resources and associated cost structure with: (1) long-term strategy 
The role of structural strategic cost management techniques in supporting ريهام صفوت firms' triple bottom line performance in supply chain context

through the design of firm's cost structure and re-engineering its value chain "structural cost management", and (2) short-term tactics through cost measurement and reduction "executional cost management", (Henri, Boiral \& Roy 2016, p.270).

Structural cost management involves tools of organizational design, product design, and process design to develop SC cost structure that is coherent with firm strategy (Anderson\& Dekker 2009 b, p. 289) that the structural cost management refers to the cost management activities aimed at changing firm's cost structure. It basically refers to the strategic decisions that typically define the framework of the firm's cost structure (Henri, Boiral \& Roy 2016, p.269-270).

That the structural cost management is a subsystem of the strategic cost management system that aims to provide management with information to take structural cost related decisions including organization design, investment and/or integration alternatives, product and process design, and operating leverage percentage.

\section{3- The role of structural strategic cost management techniques in supporting firms' TBL performance}

\section{Target costing (TC)}

TC is a proactive cost management technique was first introduced in Japan in 1960s to increase firms' competitiveness (Zengin \& Ada 
The role of structural strategic cost management techniques in supporting ريهام صفوت firms' triple bottom line performance in supply chain context

2010, p.5594). TC aims to reduce costs during the planning and designing of new products.

$\mathrm{TC}$ is a reverse costing methodology that aims to manage product's cost during the design stage to sustain product's cost competitiveness while meeting customers' specifications and standards (Zengin \& Ada 2010, p.5594).

TC takes into account customers' requirements along with product's functionality and quality measures while reducing its cost by eliminating non value adding functions and attributes during the design phase.

TC philosophy is based on some principles those are (Swenson \& Bell 2003, p.12-13);

1. Customer focus

2. $\quad$ Price led cost

3. Focusing on design

4. Value chain involvement

5. Life cycle consideration

6. Cross-functional involvement.

TC allows firm to identify structural cost drivers in product design and development stage and use them in strategic cost management through;

1. Selecting technological and technical level.

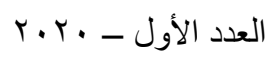


The role of structural strategic cost management techniques in supporting ريهام صفوت

firms' triple bottom line performance in supply chain context

2. Determining production lines variability and the degree of horizontal integration.

3. Determining product's complexity and attributes depending on customers' requirements.

4. Determining the degree of vertical integration.

TC can support firms' TBL performance by deploying their TBL objectives at early products development stages that TC can help firms to afford strategic social and environmental objectives into the whole life cycle of products by selecting choices those are environmental friendly and support social and environmental programs.

Previous studies found that about 70 to $80 \%$ of products' life cycle costs are determined by designers in stages prior to the conceptual design stage (Bradley, R. et al., 2016, p.371) that the ability to integrate TBL features and influence TBL impact is high at the early $R \& D$ and design stages also the cost of design changes at that stages is significantly lower than late designing stages, which necessitate early consideration of TBL dimensions in product's development life cycles that can be done by integrating social and environmental considerations in TC mechanism. 
The role of structural strategic cost management techniques in supporting

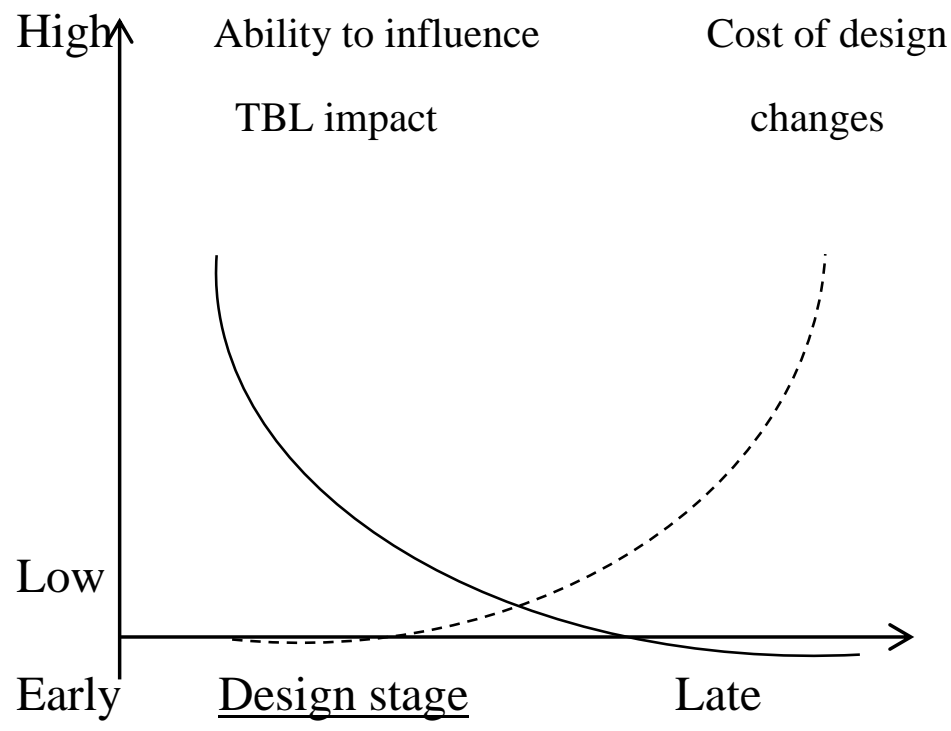

Figure 1: Design cycle cost commitment (Bradley, et al., 2016, p.371).

\section{Three dimensional concurrent engineering (3DCE)}

3DCE was first introduced in the late 1990s and it is about the concurrent integration of product design into processes and SC design (Marsillac \& Jungbae Roh, 2014, p.318), 3DCE is "the simultaneous and coordinated design of products, manufacturing processes, and SCs".

1- $\quad$ Product design 
The role of structural strategic cost management techniques in supporting ريهام صفوت firms' triple bottom line performance in supply chain context

It is about configuring product's features and functions that would meet customers' expectations and needs, and it is easier to include TBL features to products at that stage. Product design includes many choices including material selection the following;

- Developing new products

- Selecting operation management tools

- Selecting production practices

- Redesigning existing products

\section{2- $\quad$ Processes design}

Processes design result in the commitment to long term capital investment and involves the selection between many choices and includes many issues such as;

- Process continuous improvement

- Redesigning existing processes

- Increasing production line efficiency

\section{3- $\quad \underline{\underline{\text { SC design }}}$}

Including SC issues at early design stages that would help in better coordination between the firm and other SC parties, reducing time to market, reducing inventories, supporting products' quality, and reducing costs from one side and also better incorporation of green and social objectives in SC networks, SC design issues include; 
The role of structural strategic cost management techniques in supporting

firms' triple bottom line performance in supply chain context

- Local SC and globalization

- Supply network design

- Suppliers' selection

- Distribution network design

- Transportation decisions.

Benefits of 3DCE (Marsillac \& Jungbae Roh, 2014, p.318, فتيح، ولاء $r \cdot I V)$

1. Connecting between firm's different departments and firm's SC that would improve product's value chain

2. Reducing product's design and development times

3. Reducing design changes and redesign time and cost

4. Reducing time to market that would result in improved market share

5. Increasing processes' flexibility

6. Improving customers' satisfaction and service level

7. Solving logistical and distribution problems and supporting product's quality

8. Reducing inventories and inventorying costs.

3DCE develops the design process and also early involvement of suppliers in process and product design would provide potential environmental benefits by selecting suppliers with environment friendly materials, putting plans to reduce energy consumption, use cleaner or renewable energy sources, use cleaner transportation

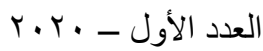
94 مجلة المحاسبة و المر اجعة لإتحاد الجامعات العربية 
The role of structural strategic cost management techniques in supporting ريهام صفوت firms' triple bottom line performance in supply chain context

means, and reduce final product's disposal wastes, and also helps in considering mutual social programs and in meeting social norms and specifications.

\section{$\underline{\text { Sustainable supply chain management (SSCM) }}$}

SSCM is defined by Seuring and Müller (2008) as: "The management of material, information, and capital flows as well as cooperation among companies along the supply chain while taking goals from all three dimensions of sustainable development, i.e. economic, environmental and social, into account which are derived from customer and stakeholder requirements" (Seuring and Müller 2008 p.1700).

Gualandris, J. et al., (2014) defined SSCM as "a new archetype for companies to meet stakeholders requirement and improve profit and competitiveness while raising ecological efficiency and social responsibility in their supply chains" (Gualandris, Golini \& Kalchschmidt, M. 2014, p.258).

Previous studies proposed that there are three dimensions of SSCM (Ni \& Sun, 2019, p. 1178) those are;

1. Inbound sustainability: TBL efforts with suppliers and upstream firms.

2. Internal sustainability: TBL operations and efforts inside the firm. 
The role of structural strategic cost management techniques in supporting ريهام صفوت

firms' triple bottom line performance in supply chain context

3. Outbound sustainability: TBL efforts with downstream firms of the SC or the demand side.

Where a successful SSCM implementation depends on the existence of the three dimensions.

SSCM activities include; sustainable design, procurement, manufacturing, storage, marketing, and transportation.

As the strategic cost management tools have developed and they have an effective role in controlling the financial, environmental, and social features in the scope of green SCs, SSCM can be considered as an important structural strategic cost management during the various stages of design, procurement, manufacturing, storage, transportation and distribution, and after sales services.

SSCM practices including;

- $\quad$ Managing logistic activities

- $\quad$ Strategic alliance with suppliers

- $\quad$ Strategic alliance with customers

- $\quad$ Green SC practices

- Joint SC social programs and activities

Would allow firms to reduce waste from non-value adding activities in their SC relations, focus on achieving customers' requirements, reducing costs of $\mathrm{SC}$ activities, reduce 
The role of structural strategic cost management techniques in supporting ريهام صفوت firms' triple bottom line performance in supply chain context

manufacturing cycle time, and build brand image through creative environmental and social practices.

\section{$\underline{\text { Lean manufacturing (LM) }}$}

Lean is a manufacturing and management philosophy which was first applied in the begging of 1900's in "Henry Ford" assembly 2ine(إبراهيم, أماني) 2015, p52), but the term LM was first used by Womack et al. in their book "The Machine that Changed the World" in 1990 (Taj, 2008, p. 219).

LM "aims to eliminate waste in order to deliver high quality products and services fast and timely at the lowest cost" (Danese, Manfè \& Romano 2018), LM utilizes the less or the minimum of everything to reach to the intended results.

LM considers anything other than the minimum amount of materials, equipment, place, and working time which are essential to the manufacturing process as waste and there are seven types of waste to be eliminated (Taj, 2008, p. 219):

1. waste from overproduction,

2. waste of waiting time,

3. transportation waste,

4. inventory waste,

5. processing waste,

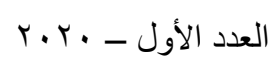


The role of structural strategic cost management techniques in supporting
6. waste of motion,
7. and waste from product defects

and the researcher add to them waste from over-processing and unutilized employees' creativities and skills.

LM is a socio-technical philosophy that works in reducing waste from transactions with buyers and suppliers across the SC إبراهيم, 2015, p55, 56), that integrating lean with SCM would better supports firm's TBL performance.

The adoption of LM principles helps in achieving environmental objectives due to better utilization of natural resources and reduction of emissions (Schulz \& Flanigan, 2016, p.451). 
The role of structural strategic cost management techniques in supporting ريهام صفوت firms' triple bottom line performance in supply chain context

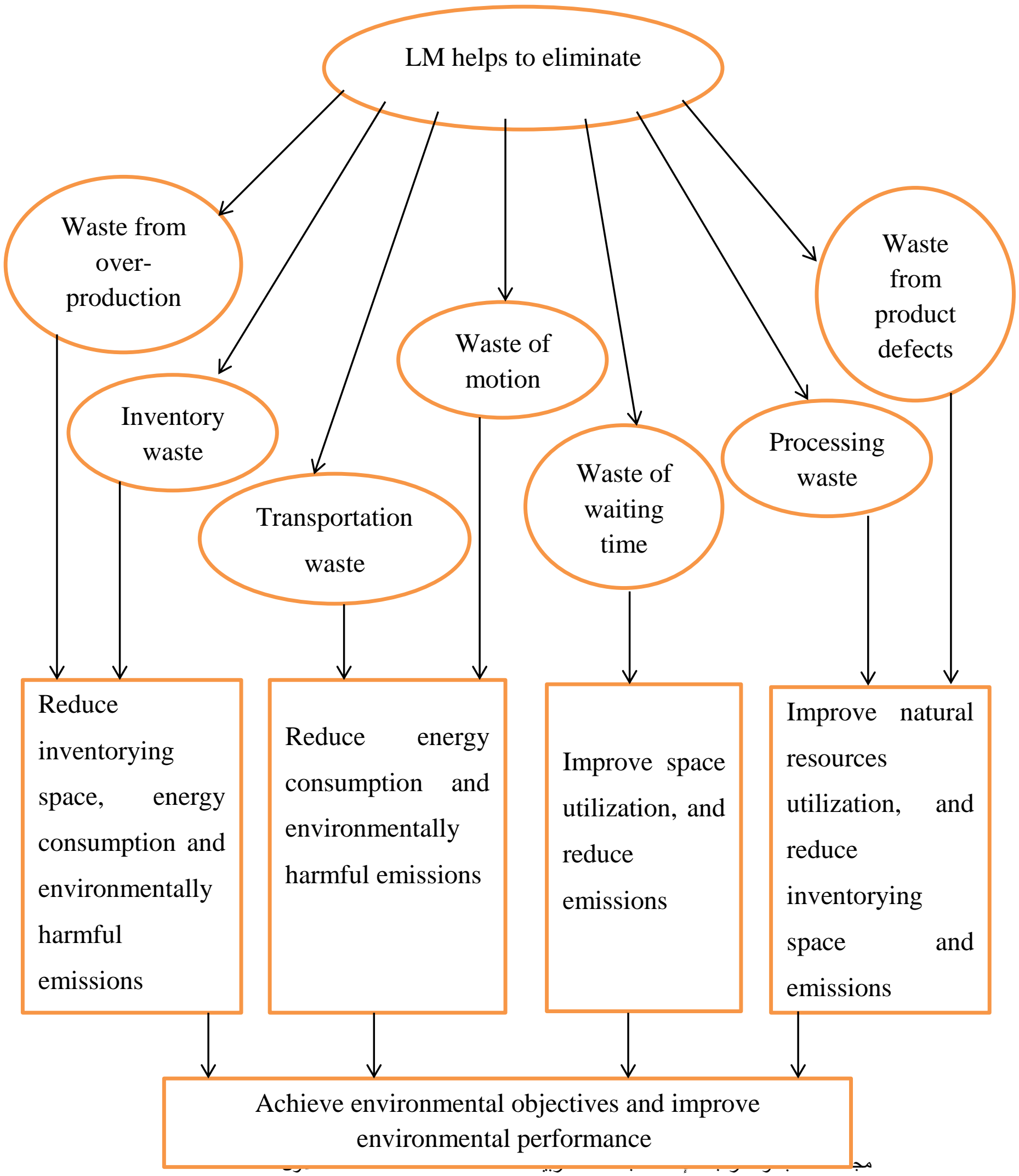


The role of structural strategic cost management techniques in supporting ريهام صفوت

firms' triple bottom line performance in supply chain context

\section{Figure 2: LM role in improving environmental performance}

Also one of the main concepts of lean philosophy is employees' empowerment and training, also LM promote working environment, support safer operating conditions and increase employees' satisfaction and commitment that supports firm's social objectives (León \& Calvo-Amodio, 2017, p.4392), And previous literature found that social responsibility programs including employees' training and development would help in creating and sustaining intellectual capital (Schulz \& Flanigan, 2016, p.451) which in return supports firm's social and financial performance.

\section{4- Research conclusions}

1. TBL performance is the performance that achieves the strategic and interrelated financial, environmental, and social objectives simultaneously and it has been regarded as a top priority in modern business conditions

2. Structural cost management is a subsystem of the strategic cost management system that aims to provide management with information to take structural cost related decisions including organization design, investment and/or integration alternatives, product and process design, and operating leverage percentage

3. $\mathrm{TC}$ is the basis for determining cost reduction opportunities both inside the firm (its internal value chain) and

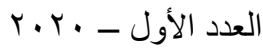
$9 \wedge$ مجلة المحاسبة و المراجعة لإتحاد الجامعات العربية 
The role of structural strategic cost management techniques in supporting ريهام صفوت

firms' triple bottom line performance in supply chain context

in its SC related activities and also it provides a great opportunity for integrating TBL objectives at early products' development stages.

4. 3DCE is related to the mutual design of $\mathrm{SC}$, product, and processes which allows firm's management to choose products, processes, and SC design alternatives that would achieve firm's TBL strategies and objectives.

5. SSCM practices allow firms to reduce waste from nonvalue adding activities in SC relations, focus on achieving customers' requirements, reducing costs of SC activities, reduce manufacturing cycle time, and build brand image through creative environmental and social practices.

6. The application of LM supports firms' TBL performance as it reduces manufacturing costs through more efficient use of resource, improves natural resources utilization, reduces inventorying space, energy consumption, and environmentally harmful emissions, also LM enhances employees' empowerment and training and promotes working environment, and supports safer operating conditions and employees' commitment.

\section{$\underline{\text { Future studies }}$}

The current research studied the role of TC, 3DCE, SSCM and LM in supporting firms' TBL performance where future studies can 
The role of structural strategic cost management techniques in supporting ريهام صفوت firms' triple bottom line performance in supply chain context

examine the role of other structural strategic cost management in supporting firms' TBL performance and the possible integration between those techniques and the effect of such integration upon firms' TBL performance, or the integration between executional and structural strategic cost management techniques firms' TBL performance to support firms' TBL performance, also future studies can examine the difficulties facing firms' TBL performance in SC context and problems related to the measurement TBL performance in SC context. 
The role of structural strategic cost management techniques in supporting ريهام صفوت

firms' triple bottom line performance in supply chain context

\section{References}

Anderson, Shannon W. \& Dekker, Henri C. (2009b) "Strategic cost management in supply chains, part 2: executional cost management" Accounting Horizons, Vol. 23, Issue 3, pp. 289-305.

Bradley, R. et al., (2018) "A total life cycle cost model (TLCCM) for the circular economy and its application to post-recovery resource allocation" Resources, Conservation and Recycling, Vol. 135, Pp. 141-149

Carter, C. R. \& Rogers, D. S., (2008) "A framework of sustainable supply chain management: moving toward new theory", International Journal of Physical Distribution \& Logistics Management, Vol. 38, Issue 5, pp.360-387.

Danese P., Manfè V., and Romano p., (2018), "A Systematic Literature Review on Recent Lean Research: State-of-the-art and Future Directions" International Journal of Management Reviews, Vol. 20, 579-605

Ellram, Lisa M. \& Stanley, Linda L. (2008) "Integrating strategic cost management with a 3DCE environment: Strategies, practices, and benefits", Journal of Purchasing and Supply Management, Vol. 14, Issue 3, Pp. 180-191

Gualandris, Jury, Golini, Ruggero, and Kalchschmidt, Matteo (2014) "Do supply management and global sourcing matter for firm sustainability performance?: An international study", Supply Chain Management: An International Journal, Vol. 19 Issue: 3, pp.258-274

Henao, R., Sarache, W., and Gómez, I. (2019) "Lean manufacturing and sustainable performance: Trends and future challenges" Journal of Cleaner Production, Vol. 208, Pp. 99116 
The role of structural strategic cost management techniques in supporting ريهام صفوت

firms' triple bottom line performance in supply chain context

Henri, Jean-François, Boiral, Olivier, and Roy, Marie-Josée (2016)

"Strategic cost management and performance: The case of environmental costs" The British Accounting Review, Vol. 48, Issue2, pp. 269-282

León, Hilda C. Martínez \& Calvo-Amodio, Javier (2017) "Towards lean for sustainability: Understanding the interrelationships between lean and sustainability from a systems thinking perspective" Journal of Cleaner Production, Vol. 142, Part 4, Pp. 4384-4402

Longoni, Annachiara \& Cagliano, Raffaella (2015)," Environmental and social sustainability priorities: Their integration in operations strategies ", International Journal of Operations \& Production Management, Vol. 35, Issue 2, pp. 216 - 245

Mani, V., Gunasekaran, A., and Delgado C., (2018) "Supply chain social sustainability: Standard adoption practices in Portuguese manufacturing firms" International Journal of Production Economics, Vol. 198, Pp. 149-164

Marsillac, Erika \& Jungbae Roh, James (2014)"Connecting product design, process and supply chain decisions to strengthen global supply chain capabilities" International Journal of Production Economics, Vol. 147, Part B, pp. 317-329

$\mathrm{Ni}$, Wenbin \& Sun, Hongyi (2019) "The effect of sustainable supply chain management on business performance: Implications for integrating the entire supply chain in the Chinese manufacturing sector", Journal of Cleaner Production, Vol. 232, Pp. 1176-1186

Otley, David (2016) "The contingency theory of management accounting and control: 1980-2014" Management Accounting Research, Vol. 31, pp. 45-62 
The role of structural strategic cost management techniques in supporting ريهام صفوت firms' triple bottom line performance in supply chain context

Schulz, Steven A., \& Flanigan, Rod L., (2016) "Developing competitive advantage using the triple bottom line: a conceptual framework" Journal of Business \& Industrial Marketing, Vol. 31, Issue 4, pp.449-458

Seuring, Stefan \& Müller, Martin (2008) "From a literature review to a conceptual framework for sustainable supply chain management", Journal of Cleaner Production, Vol. 16, No. 15, pp.1699-1710

Shank, John K., \& Govindarajan, V., (1993), "Strategic Cost Management: The New Tool for Competitive Advantage", New York: Free Press, https://books.google.com.eg

Swenson D., \& Bell, J., (2003) "Best practices in target costing" Management Accounting quarterly winter, Vol.4, No.2, pp.12-17

Taj, Shahram (2008) "Lean manufacturing performance in China: assessment of 65 manufacturing plants", Journal of Manufacturing Technology Management, Vol. 19, Issue 2, pp.217-234

Varsei, Mohsen, et al., (2014) "Framing sustainability performance of supply chains with multidimensional indicators", Supply Chain Management: An International Journal, Vol. 19, Issue 3, and pp. $242-257$

Zengin, Yasemin \& Ada, Erhan (2010) "Cost management through product design: target costing approach" International Journal of Production Research, Vol. 48 Issue 19, Pp. 5593-5611

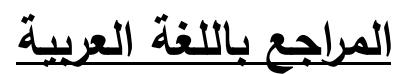

إبراهيم، أماني كمال محمد (10 (10) "نموذج مقترح لتطوير أداء نظم التكاليف

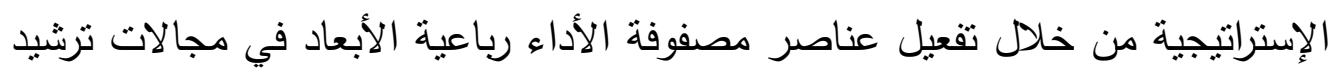

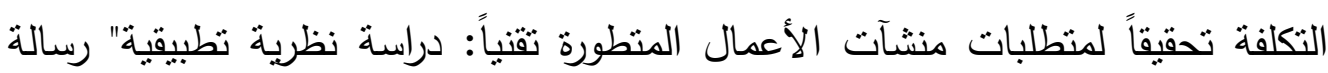
دكتوراه غير منشورة، قسم المحاسبة، كلية النجارة، جامعة بني سويف لاعنال

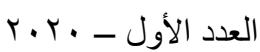
مجلة المحاسبة و المراجعة لإتحاد الجامعات العربية 
The role of structural strategic cost management techniques in supporting ريهام صفوت firms' triple bottom line performance in supply chain context

فتيح، ولاء محمد عبد العليم عبد العظيم (Y IV) "أثنز التكامل بين سلاسل العرض ونماذج الأداء المتزامن علي إدارة التكلفة الإستراتيجية: بالتطبيق علي منشآت الأعمال المصرية" رسالة دكتوراه غير منشورة، قسم المحاسبة والمراجعة، كلية التجارة، جامعة قناة السويس 